\title{
Popularization of Carbon Capture and Storage Technology in Society: Principles and Methods
}

\author{
Alexey Cherepovitsyn ${ }^{1}$, Tatiana Chvileva ${ }^{1, *(1)}$ and Sergey Fedoseev ${ }^{2}$ \\ 1 Organization and Management Department, Saint Petersburg Mining University, 2, 21st Line, \\ 199106 Saint-Petersburg, Russia; Alekseicherepov@inbox.ru \\ 2 Luzin Institute for Economic Studies-Subdivision of the Federal Research Centre "Kola Science Centre of \\ the Russian Academy of Sciences", 24a, Fersman St., 184209 Apatity, Russia; S.fedoseev@ksc.ru \\ * Correspondence: Chvileva_TA@pers.spmi.ru; Tel.: +7-981-717-22-42
}

Received: 9 September 2020; Accepted: 9 November 2020; Published: 12 November 2020

\begin{abstract}
The problem of global warming is a key challenge. One means to prevent climate change is to reduce the concentration of carbon dioxide in the atmosphere. This can be achieved using $\mathrm{CO}_{2}$ capture and storage (CCS) technology. Due to the relative novelty of the technology, low level of experience, and high risk of implementation, in practice society often displays a negative attitude towards CCS projects. Thus, it is necessary to develop a targeted strategy to popularize $\mathrm{CO}_{2}$ capture and storage technology. Based on an extensive literature review and the experience of implementation of CCS projects in different countries, this study demonstrates the necessity of applying the deficit, contextual, lay expertise, and public participation models to promote CCS technology. As a result, the factors influencing the choice of promotion tools are identified, and the measures to popularize CCS technology, depending on the stage of its implementation, are determined. Recommendations for the improvement of CCS public databases are developed. The methodologies used this study include case studies, system-oriented analysis, and stakeholder management tools.
\end{abstract}

Keywords: environmental technology; carbon capture and storage; carbon dioxide; popularization of technology; public perception; social license to operate

\section{Introduction}

Technological development has a significant influence on modern society and has helped address a number of global problems, including climate change, resource depletion, and ecosystem loss [1-4]. However, in recent decades, the academic community has faced questions about the development of the theoretical aspects of human knowledge and the popularization of the results of scientific studies [5-7]. Due to a lack of understanding of new technology and concerns about its safety, the public may not approve the use of some technological solutions in practice. To obtain a social license to introduce new technologies, federal, state, and local governments, the scientific community, and private businesses should develop and implement goal-oriented strategies aimed at receiving approval for their activities from a wide range of stakeholders [8].

In recent decades, the problem of climate change has become one of the most discussed issues internationally. According to the Intergovernmental Panel on Climate Change's (IPCC) [9], "several regional changes in climate are assessed to occur with global warming up to $1.5{ }^{\circ} \mathrm{C}$ compared to pre-industrial levels, including warming of extreme temperatures in many regions (high confidence), increases in frequency, intensity, and/or amount of heavy precipitation in several regions (high confidence), and an increase in intensity or frequency of droughts in some regions (medium confidence)" [9]. 
On 23 June 1988, Dr. James Hansen (an Adjunct Professor at Columbia University's Earth Institute (USA), where he directs a program in Climate Science, Awareness and Solutions) testified before the U.S. Senate Committee on Energy and Natural Resources that "the warming trend was not a natural variation but was caused by a buildup of carbon dioxide and other artificial gases in the atmosphere" [10]. Since the late 1970s, James Hansen has focused his research on Earth's climate and, in particular, anthropogenic climate change. Hansen's testimony helped to increase public awareness of global warming. Subsequently, a cause and effect relationship between the greenhouse effect and climate change has been confirmed by international academic research [11-14].

Anthropogenic greenhouse gas emissions are dominated by fossil $\mathrm{CO}_{2}[15,16]$. According to the BP Statistical Review of World Energy 2020 [17], the volume of global carbon dioxide emissions (through consumption of oil, gas, and coal for combustion-related activities) was 34,169 billion tons in 2019, which was $0.5 \%$ higher than in 2018 [17]. $\mathrm{CO}_{2}$ emissions in 2019 were about $60.1 \%$ higher than in 1990 and $44.3 \%$ higher than in 2000 [18].

The importance of reducing environmental pollution and carbon dioxide emissions has been emphasized in the studies of numerous researchers [14,19-23]. At the global level, climate change has become an important influencing on the decision-making process of governments, organizations, and societies, particularly in economically developed countries. Strict requirements exist globally to reduce greenhouse gas emissions. For example, the European Union has committed to being climate-neutral by 2050 [24]. In September 2020, the European Commission proposed raising its 2030 greenhouse gas emission reduction target to at least 55\% compared to $1990[25,26]$. The existing target for 2030 is to reduce greenhouse gas emissions to at least 40\% compared to 1990 [26].

The implementation of new more efficient and environmentally friendly technologies is an important part of low-emission development strategies (LEDS). Carbon capture and storage (CCS) and carbon capture and utilization (CCU) technologies are considered options for reducing anthropogenic carbon dioxide emissions [27-30]. Carbon capture and storage involves capturing carbon dioxide from emission sources, transporting it to a storage site, and burying it in a suitable underground geological formation [31]. Carbon capture and utilization involves the capture of $\mathrm{CO}_{2}$ from emission sources and its subsequent use as a resource to create valuable products or services [23].

Carbon capture and storage technology began to be applied in the 1920s to separate carbon dioxide found in gas fields from commercial methane. In the early 1970s, $\mathrm{CO}_{2}$ was captured at a gas processing plant in Texas (USA), transported by pipeline to a nearby oil field, and then injected into reservoirs for enhanced oil recovery [32]. Today the efficiency of CCS and CCU technologies is proven by the successful realization of a large number of projects around the world [30,33].

The technology of sequestration of $\mathrm{CO}_{2}$ (for example, carbon farming or urban forestry) also has proven to be an effective measure for the reduction in carbon dioxide in the atmosphere [34-38].

However, in our opinion, $\mathrm{CCS}, \mathrm{CCU}$, and sequestration of $\mathrm{CO}_{2}$ technologies are characterized by various risks, and, as a result, are perceived differently by a wide range of stakeholders [39-42]. Thus, in our research we considered carbon capture and storage technology.

CCS projects are accompanied by a large number of risks, including leaks, accidents, environmental pollution, and danger to public health [43,44], and can have significant negative impacts on a wide range of stakeholders, particularly local communities [45-49]. This increases the social risks associated with the implementation of relevant projects.

The relative novelty of carbon capture and storage technology, low level of experience, and high risk of implementation often translate into a negative public perception of CCS in practice. Stakeholders make decisions about their attitude to a project without a clear understanding of all aspects of CCS technology. Separate groups of stakeholders frequently oppose the implementation of carbon capture and storage technology [50]. This can result in the delay or postponement and, in some cases, the cancellation of project activities [51].

Thus, the implementation of measures aimed at the popularization of innovative environmental technologies (including carbon capture and storage) is required. This will help raise awareness of 
CCS content, risks, and social benefits [52], and will allow stakeholders to make more informed and rational decisions regarding the implementation of specific projects.

The aim of this study was to find and justify the effective ways to promote carbon capture and storage technology to obtain a social license for its implementation.

The key objectives of the paper are:

- Analysis of the literature dedicated to modern approaches to the popularization of new technologies in society;

- Identification of the factors affecting the choice of tools for the popularization of CCS technology in society and the effectiveness of their application;

- Development of the principles of CCS technology popularization;

- Identification of advantages and disadvantages of various methods of popularization of carbon dioxide capture and storage technology.

\section{Materials and Methods}

The research framework includes four steps (Figure 1).

Step 1. Literature review and systematization of existing models and methods of increasing public acceptance of new technologies and scientific achievements.

Step 2. Literature review and systematization of CCS projects implemented around the world and their level of acceptance in society.

Step 3. Identification of factors influencing the choice of tools for promoting CCS technology in society and the effectiveness of their application.

Step 4. Justification of measures to popularize CCS technology, depending on the stage of its implementation and the target group of stakeholders.

Figure 1. Scheme of the research framework.

In each of these individual steps, various methods and materials were used, as summarized below.

Steps 1 and 2: A desk study was carried out to generalize, analyze, and systematize, firstly, information on the assessment of societal attitudes towards the development of science and technology, and the methods of increasing public awareness in this area, and secondly, information on CCS projects implemented around the world and their level of acceptance and approval by stakeholders.

The purpose of step 1 was to investigate modern approaches to the popularization of science and new technologies in society. This step included an overview of the reports developed by the Royal Society (UK) [53], the Lords Science and Technology Committee (UK) [54], and the Research 
Bureau Limited [55]. The analysis also included a revision of the available reviewed papers published on scientific platforms such as Elsevier Science Direct, Elsevier Scopus, and ResearchGate. The selection of the literature was made based on a few keywords, such as "technology popularization", "science popularization", and "science and society".

The purpose of step 2 was to analyze the implementation progress of CCS projects and identify the key reasons why projects were accepted or rejected by stakeholders. The study included a comprehensive analysis of:

- Open-access databases (the National Energy Technology Laboratory's Carbon Capture and Storage Database [56], the database of CCS facilities of the Global CCS Institute [57], and the CCS project database provided by the Carbon Capture and Sequestration Technologies at MIT [58]);

- Reports, outlooks, statistics, and data of the Global CCS Institute [59,60], the Intergovernmental Panel on Climate Change (IPCC) [9,61], and the Institute for Sustainable Energy, Environment and Economy [62];

- Available reviewed papers. The analysis was conducted based on a few keywords, such as "CCS project", "carbon capture and storage", "social license to operate", "CCS project perception", and "CCS project attitude".

The case studies method was used in this part of the research.

Step 3: The inductive method (deriving conclusions about influences on the effectiveness of the various popularization methods from individual cases of carbon capture and storage projects), synthesis (combining different aspects of public attitude to CCS technology), case studies method, and stakeholder management tools were used in this part of the research.

Step 4: The purpose of step 4 was to adopt existing models for promoting science and its achievements in society, and to develop an approach to carbon capture and storage technology popularization, taking into account its specific features. The case studies method, system-oriented analysis, stakeholder management tools, and project management tools were used in this part of the research.

CCS projects are characterized by multiple and varied dimensions, including social, technological, economic, and environmental dimensions. This paper examines research from three dimensions: social aspects of CCS projects (society's attitude to CCS technologies, issues of safety for present and future generations, social effect), environmental aspects of CCS projects (proven ability of CCS technologies to reduce emissions of anthropogenic carbon dioxide and influence climate change), and technological aspects of CCS projects (complex technological chain (capture, transportation, injection), accompanied by significant risks, including leaks and accidents).

\section{Theoretical Framework}

Issues related to the attitude of society regarding the development of scientific knowledge, understanding of new technologies, and recognition of their value began to be raised by researchers in the second half of the 20th century. One of the fundamental works in this area is the report of the Royal Society (UK) entitled "The Public Understanding of Science" (1985) [53]. The report recognized a need to monitor and assess society's attitudes towards the development of science and technology. According to "The Public Understanding of Science", it is necessary to increase public awareness in this area, including through the implementation of educational programs. Consistent with the recommendations from the Royal Society, the key goal of interaction between scientists, industry, and society is to raise awareness of new technologies that will contribute to their public approval. This concept is called the public understanding of science (PUS) [63,64].

In the 1990s, research was conducted to identify a correlation between the level of knowledge about new technologies and attitudes towards their use. It was found that understanding by stakeholders of the content, risks, and benefits of the implementation of new technologies does not always lead to the formation of a favorable public perception [65-67]. 
Considering the results of the above-mentioned studies, in addition to rapid technological change, the concept of public understanding of science (PUS) was deemed irrelevant. It was replaced by a new concept: "public engagement with science and technology" (PEST) [68,69].

In 2000, the Lords Science and Technology Committee (UK), in their report "Science and Society", recommended moving from informing society about the results of technological change, to actively involving society in the decision-making process related to the development and implementation of new technologies. This process of involvement must be carried out with the use of public consultation tools, focus groups, participation of stakeholders in panel discussions, and conferences [54].

Within the framework of this approach, various models of popularization of scientific knowledge and new technologies were formulated. Thus, in the report "Science and the Public: Mapping Science Communication Activities" (Research International), three models were suggested: the deficit model, the consultation model, and the engagement model [55]. Bruce V. Lewenstein proposed four models for the popularization of science and its achievements in society: the deficit model, the contextual model, the lay expertise model, and the public participation model [70].

In 2016, the Lords Science and Technology Committee (UK) published "Science communication and engagement", which noted the importance of implementing a state policy of involving society in the decision-making process regarding scientific and technological development [71].

The evolution of a social license concept has reinforced the importance of actively involving stakeholders in the development and implementation of new technologies [72,73]. This concept involves the active participation of local communities and other stakeholders in the planning and implementation of industry projects [74,75]. Furthermore, consistent with this concept, it is necessary to track the opinions and interests of society $[76,77]$.

In recent years, characterized by the rapid development of Internet technologies, the toolkit for interaction with stakeholders in the framework of practical implementation of achievements of scientific and technological progress has expanded. This, in a report of the National Academies of Sciences (USA) entitled "Communicating Science Effectively: A Research Agenda", social networks are considered an effective tool for promoting scientific thought and new technologies in society [78].

The considered practices of popularizing scientific achievements and new technologies in society can be applied within the framework of building a strategy for promoting carbon capture and storage technology. However, it is necessary to take into account specific characteristics of CCS.

CCS technology is applicable to different industries (natural gas processing, power generation, iron and steel production, etc.). The key prerequisites for the implementation of CCS projects include the following:

- Availability of permanent sources of $\mathrm{CO}_{2}$ emissions;

- Availability of underground storage located close to sources (for example, deposits at a late stage of development and deep-lying aquifers);

- Availability of prospects for creating infrastructure for the implementation of the project.

However, implementation of carbon capture and storage is accompanied by a number of barriers that need to be overcome $[79,80]$ :

1. Technical barriers.

$\mathrm{CCS}$ consists of a number of complex processes, including $\mathrm{CO}_{2}$ separation, compression, transport, injection into underground reservoirs, and long-term monitoring. The implementation of these processes can be accompanied by leaks, accidents, environmental pollution, danger to public health, etc.

2. Legal and regulatory barriers.

Because of its relative novelty, in a number of countries in which the implementation of CCS technology has significant potential, no specific legislation exists that regulates such projects. Prior to a CCS project's implementation, it is necessary to introduce clear legislation for $\mathrm{CO}_{2}$ capture and storage. A lack of specific legislation causes a CCS project to be postponed or canceled [33]. 
3. Economic barriers.

CCS projects are characterized by high capital costs, financial problems and risks, and funding problems.

4. Public perception barriers (public awareness and acceptance).

As mentioned previously, separate groups of stakeholders frequently oppose the implementation of carbon capture and storage technology [50].

International experience of the implementation of carbon capture and storage technology shows that public acceptance can be crucial for the success of these projects [50,51]. According to research conducted in Germany, public perception is the second greatest barrier (after economic factors) to the implementation of CCS [81].

Since the 2000s, a significant amount of scientific research devoted to public perception of carbon dioxide capture and storage has been published. The studies can be divided into:

- Publications containing the results of sociological surveys aimed at identifying the attitude of stakeholders to CCS technology and the factors that determine this attitude [62,82-85];

- Publications reflecting mechanisms of interaction with stakeholders in the framework of carbon dioxide capture and storage projects [59,86-88];

- Publications describing experiences of implementation of CCS projects in different countries, the attitude of stakeholders to these projects, and mechanisms of interaction with stakeholders during the projects' life cycle $[51,60,89,90]$.

Public opinion polls conducted by researchers show a low level of awareness of carbon dioxide capture and storage technology [91] and a high level of concern about its use [92,93]. Thus, despite the experience of implementation of CCS demonstration projects in various countries, including Australia, Japan, and the Netherlands, public perception of this technology is at a relatively low level [94]. This can, in some cases, negatively affect the implementation of specific carbon dioxide capture and storage projects [51].

In spite of the fact that, as mentioned above, the problems of the popularization of science and its achievements are being actively considered by researchers, the most effective methods of promoting CCS technology, taking into account all of its features and risks, have not yet been justified.

\section{Results}

\subsection{An Approach to the Popularization of Carbon Dioxide Capture and Storage Technology}

As mentioned above, in his work "Models of public communication of science and technology" [70], Bruce V. Lewenstein proposed four models of popularization of science and its achievements in society: the deficit model, the contextual model, the lay expertise model, and the public participation model (Figure 2). 

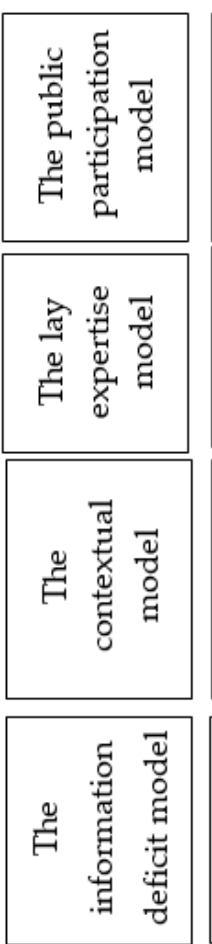

The key points of the model:

- it is necessary to involve a wide range of stakeholders that will contribute to the increase in their level of confidence and allow stakeholders to exercise control over the implementation of new technology.

\section{The key points of the model:}

- experience, cultural values, and knowledge of stakeholders should be taken into account in the process of interaction;

- first of all, consultation is carried out among local communities.

\section{The key points of the model:}

- various stakeholders perceive information in different ways;

- it is necessary to adapt the content of information about the development of science and new technologies provided to the general public depending on the audience characteristics.

The key points of the model:

- a skeptical attitude of society towards science and its achievements is often caused by a lack of information;

- it is necessary to inform society about scientific achievements and new technologies.

\begin{tabular}{|c|}
\hline $\begin{array}{c}\text { Applied } \\
\text { strategy - } \\
\text { involvement }\end{array}$ \\
\hline \begin{tabular}{c} 
Applied \\
strategy - \\
consultation \\
\hline Applied \\
strategy - \\
adaptation
\end{tabular} \\
\hline
\end{tabular}

\section{Applied}

strategy informing

Figure 2. The content of models of popularization of science and technology in society [70]. Compiled by authors based on [70].

The deficit model is often criticized. Researchers believe that raising awareness of new technologies will not always increase approval of their implementation among a wide range of stakeholders. Thus, the efficiency of the public participation model is recognized [95].

Justification of the application of various models of popularization of carbon capture and storage technology is presented in Figure 3.

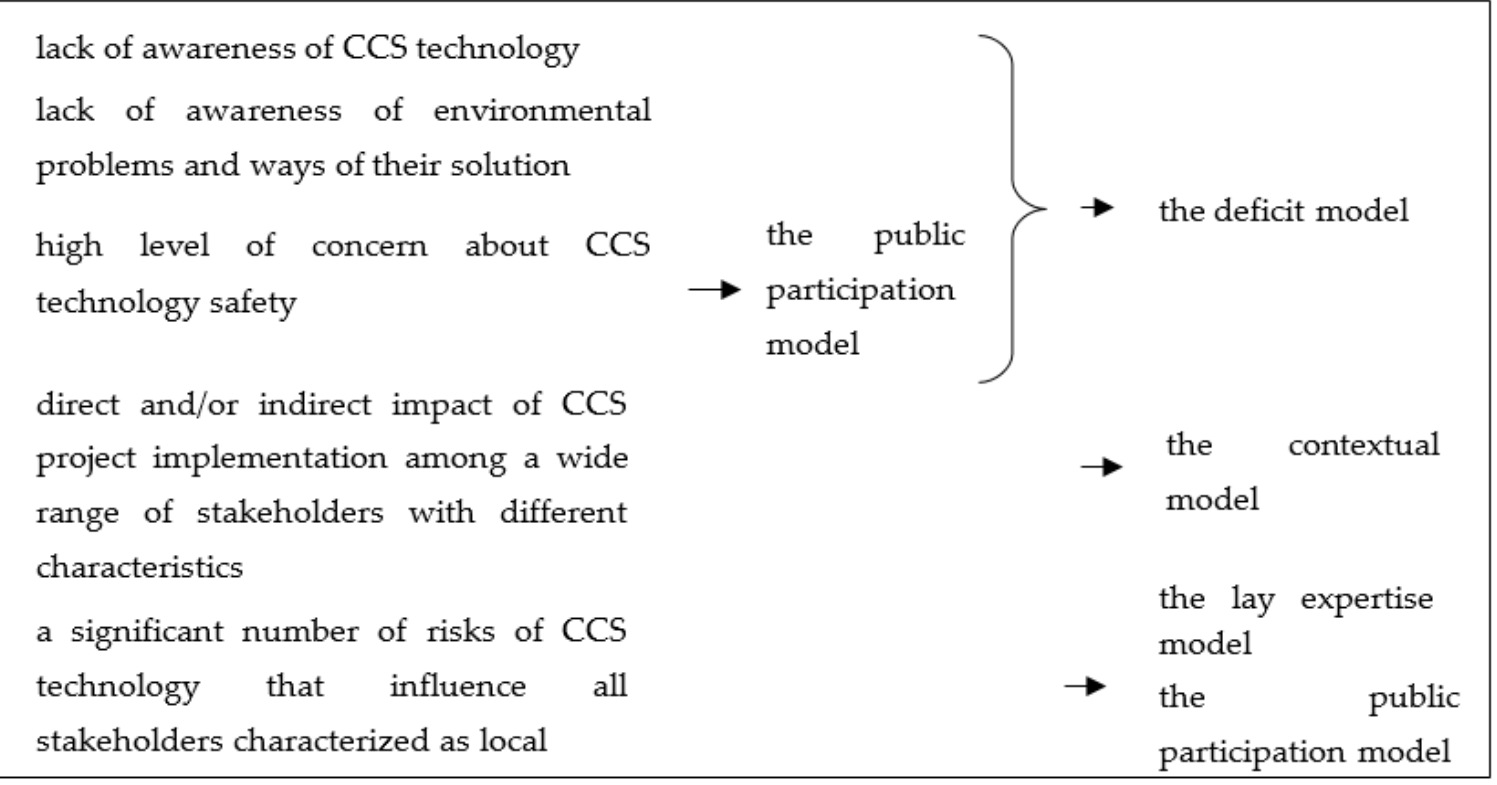

Figure 3. Justification of the application of various models of popularization of carbon capture and storage technology. 
The content of models of popularization of scientific achievements and new technologies in society in relation to CCS is presented in Figure 4.

\begin{tabular}{|c|c|c|}
\hline \multicolumn{3}{|c|}{$\begin{array}{l}\text { The deficit model } \\
\text { suggests: } \\
\text { nmental problems, including greenhouse gas emissions; } \\
\text { gy, and risks and benefits of its use; } \\
\text { CS project implementation in practice. }\end{array}$} \\
\hline $\begin{array}{l}\text { The contextual model } \\
\text { Within the framework of interaction } \\
\text { with stakeholders the following } \\
\text { characteristics of target groups should } \\
\text { be taken into account: } \\
\text { - personal characteristics; } \\
\text { - general level of education and } \\
\text { level of awareness of global } \\
\text { environmental problems, including } \\
\text { greenhouse gas emissions; } \\
\text { - level of environmental } \\
\text { responsibility and concern about } \\
\text { environmental problems; } \\
\text { - personal positive or negative } \\
\text { experience associated with the } \\
\text { implementation of CCS or mining } \\
\text { projects; } \\
\text { - degree of trust in persons } \\
\text { implementing measures aimed at } \\
\text { CCS technology popularization; } \\
\text { - degree of trust in authorities at the } \\
\text { federal, state, and locallevels. }\end{array}$ & $\begin{array}{l}\text { The lay expertise } \\
\text { model } \\
\text { suggests: } \\
\text { - identification of } \\
\text { attitude of local } \\
\text { stakeholders to the } \\
\text { implementation of CCS } \\
\text { technology; } \\
\text { - receiving feedback } \\
\text { from local stakeholder } \\
\text { groups on the } \\
\text { implementation of CCS } \\
\text { technology; } \\
\text { - identification of } \\
\text { problematic or } \\
\text { controversial aspects of } \\
\text { CCS technology } \\
\text { implementation. }\end{array}$ & $\begin{array}{l}\text { The public participation } \\
\text { model } \\
\text { suggests: }\end{array}$ \\
\hline
\end{tabular}

Figure 4. Models of popularization of scientific achievements and new technologies in society in relation to CCS.

As can be seen in Figure 4, the basic aspect of the popularization of carbon dioxide capture and storage technology is to raise the level of public awareness. The choice of method of interaction with stakeholders should be carried out taking into account the requirements of the contextual model based on the analysis of the following factors:

1. Personal characteristics of the target group, such as age, social status, income level, and gender.

A strategy for the popularization of CCS technology and formation of responsible environmental behavior should encompass people of all ages. The age of the target audience determines the content and specifics of communication.

A number of studies show a higher level of support for environmental technologies among people with higher incomes and social status, compared with representatives of the working class and unemployed [96].

Sociological surveys show a strong correlation between gender and attitudes towards CCS technology. Thus, women are more likely to oppose the use of technology because of doubts about its safety [97]. This determines the development of a strategy for the popularization of CCS projects among women from the perspective of long-term safety [97]. 
2. General level of education and level of awareness of global environmental problems, including greenhouse gas emissions.

The high level of education determines an increased interest in environmental technologies. In such conditions, a need for information is increasing.

3. Level of environmental responsibility and concern about environmental problems.

The expansion of the concept of sustainable development and rising level of environmental responsibility of civil society indicate an increased interest in environmental technologies and a readiness to perceive information.

4. Personal positive or negative experiences associated with the implementation of CCS or mining projects.

Few people have experience in the implementation of carbon dioxide capture and storage projects. However, related technologies exist that are more prevalent and can also shape the perception of CCS. For example, in a region that is a significant center of oil production, the population has more knowledge and demonstrates a more favorable perception of CCS technology.

5. Regional aspect: the degree of proximity of the target audience to the area of potential or actual CCS project implementation.

The impact of the implementation of CCS projects on various stakeholders is different. The largest number of risks is assumed by local stakeholder groups. This determines the need for continuous interaction with these stakeholders and their active involvement.

6. Degree of trust in persons implementing measures aimed at CCS technology popularization.

The low level of public awareness of carbon dioxide capture and storage technology forces stakeholders to accept the position of experts who are trusted by stakeholders.

7. Degree of trust in authorities at the federal, state, and local levels.

CCS projects require significant government control because of their size and complexity. Civil society will be more favorable to the implementation of carbon dioxide capture and storage projects, knowing that their implementation is monitored and controlled by competent authorities. State participation in the implementation of measures to popularize CCS technology will also contribute to its positive perception.

The choice of a specific method of carbon dioxide capture and storage technology popularization must be made on the basis of a preliminary analysis of the target audience (its boundaries, age, awareness, etc.).

In accordance with Figures 3 and 4, it is necessary to comprehensively apply methods aimed, firstly, at raising public awareness and, secondly, at actively involving stakeholders in the processes of CCS project implementation.

Figure 5 shows the focus of measures of CCS technologies' popularization, depending on the stage of their implementation.

Specific methods that can be used, and their advantages and disadvantages, are presented in Table 1. 
Implementation of CCS project

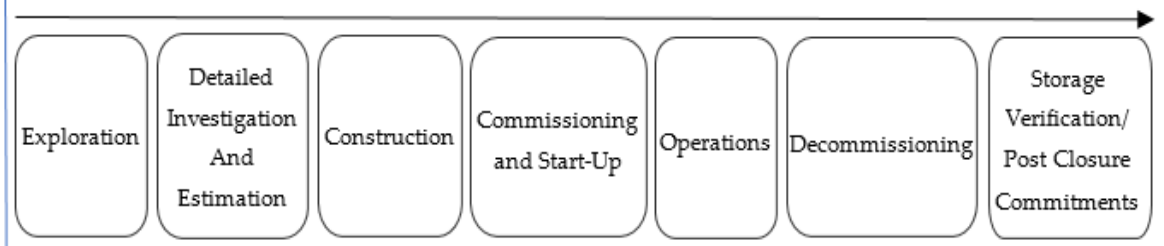

Raising awareness of Raising awareness of global environmental problems, including greenhouse gas emissions

global environmental

problems, including

greenhouse gas emissions

Raising awareness of

Carbon Capture and

Storage technology

Raising awareness of

successful CCS project

implementation

experience

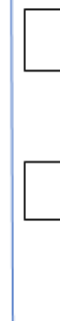

Raising awareness of Carbon Capture and Storage technology

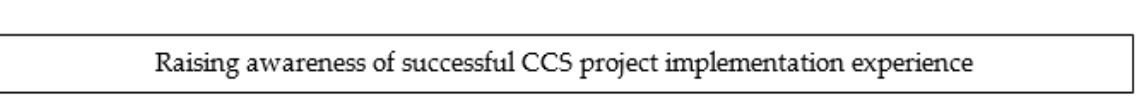

Raising awareness of the benefits of CCS project implementation to a wide range of stakeholders

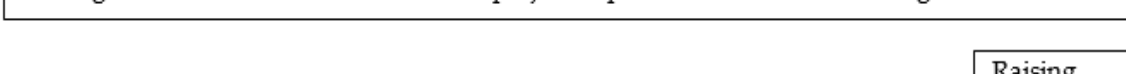

Raising

awareness

of the

Active involvement of stakeholders in CCS projects

results of

Raising awareness of the progress of the CCS

CCS

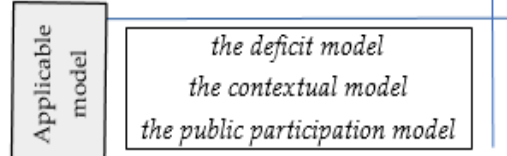

\begin{tabular}{|r|}
\hline the lay expertise model, the public participation model \\
\hline the deficit model, the contextual model \\
\hline
\end{tabular}

Raising awareness of the results of CCS project

Raising awareness of the safety of facilities in the post-project period

the deficit model

the contextual model

the public participation model

Figure 5. Direction of measures to popularize CCS technology, depending on the stage of its implementation. 
Table 1. Methods of popularization of carbon dioxide capture and storage technology and CCS projects.

\begin{tabular}{|c|c|c|c|c|}
\hline Method & Objectives of the Method & Target Group & Advantages & Disadvantages \\
\hline \multicolumn{5}{|l|}{ Educational } \\
\hline $\begin{array}{l}\text { Courses dedicated to the environmental } \\
\text { challenges facing modern society, the } \\
\text { development of technologies aimed at } \\
\text { their solutions, implemented within the } \\
\text { educational programs of secondary and } \\
\text { higher education. }\end{array}$ & Informing & Students & $\begin{array}{l}\text { Allows creation among young } \\
\text { people of ideas about ecological } \\
\text { problems and environmental } \\
\text { protection technologies, and } \\
\text { responsible behavior; } \\
\text { - Allows coverage of a wide range } \\
\text { of issues; } \\
\text { - There is a dialogue that } \\
\text { contributes to better } \\
\text { understanding of information. }\end{array}$ & - $\quad$ A limited audience. \\
\hline $\begin{array}{l}\text { Courses distributed by online } \\
\text { platforms devoted to the environmental } \\
\text { challenges facing modern society, the } \\
\text { development of technologies aimed at } \\
\text { their solution, and also to disclosure of } \\
\text { the content, risks, and benefits of CCS } \\
\text { technology. }\end{array}$ & Informing & $\begin{array}{l}\text { General public with access } \\
\text { to the Internet }\end{array}$ & $\begin{array}{l}\text { Allows a large audience to } \\
\text { be reached; } \\
\text { - Makes it possible to } \\
\text { visualize technology; } \\
\text { - } \begin{array}{l}\text { Allows coverage of a wide range } \\
\text { of issues; }\end{array} \\
\text { - There is a dialogue that } \\
\text { contributes to better } \\
\text { understanding of information; } \\
\text { - Provides easy access } \\
\text { to information; } \\
\text { - Enables permanent access } \\
\text { to information. }\end{array}$ & $\begin{array}{l}\text { - Courses are usually limited } \\
\text { in time; } \\
\text { - Method does not cover an } \\
\text { audience that does not have } \\
\text { access to a computer and } \\
\text { the Internet. }\end{array}$ \\
\hline $\begin{array}{l}\text { Educational programs (professional } \\
\text { development programs, retraining of } \\
\text { personnel) dedicated to the } \\
\text { environmental challenges facing } \\
\text { modern society, the development of } \\
\text { technologies aimed at their solution, } \\
\text { and also to disclosure of the content, } \\
\text { risks, and benefits of CCS technology. }\end{array}$ & Informing & $\begin{array}{l}\text { Representatives of } \\
\text { organizations operating in } \\
\text { the field of environmental } \\
\text { protection, oil production, } \\
\text { etc. }\end{array}$ & $\begin{array}{l}\text { - Those who enroll in the course } \\
\text { are usually motivated to study; } \\
\text { Raises awareness of } \\
\text { environmental protection } \\
\text { technologies among those who } \\
\text { can influence decisionmaking on } \\
\text { CCS implementation; } \\
\text { - Makes it possible to study in } \\
\text { depth a wide range of issues; } \\
\text { - There is a dialogue that } \\
\text { contributes to better } \\
\text { understanding of information. }\end{array}$ & $\begin{array}{ll}\text { - } & \text { A limited audience; } \\
\text { - } & \text { Programs are usually limited } \\
\text { in time. }\end{array}$ \\
\hline
\end{tabular}


Table 1. Cont

\begin{tabular}{|c|c|c|c|c|}
\hline Method & Objectives of the Method & Target Group & Advantages & Disadvantages \\
\hline \multicolumn{5}{|l|}{ Media } \\
\hline $\begin{array}{l}\text { Videos or popular science movies and } \\
\text { TV shows devoted to environmental } \\
\text { problems and environmental } \\
\text { technologies, including CCS } \\
\text { technology. }\end{array}$ & Informing & General public & $\begin{array}{l}\text { - Can be broadcast on TV channels, } \\
\text { reaching the widest } \\
\text { possible audience; } \\
\text { - Can be used repeatedly during } \\
\text { presentations, meetings, etc.; } \\
\text { - Makes it possible to } \\
\text { visualize technology. }\end{array}$ & $\begin{array}{l}\text { - Videos, popular science } \\
\text { movies, and TV shows that } \\
\text { touch on complex, technical } \\
\text { issues may not be fully } \\
\text { understood by the audience; } \\
\text { - High financial costs; } \\
\text { - Method does not allow the } \\
\text { audience to ask questions, } \\
\text { there is no dialogue. }\end{array}$ \\
\hline $\begin{array}{l}\text { Coverage of environmental problems } \\
\text { and environmental technologies, } \\
\text { including CCS technology, in the print } \\
\text { media. }\end{array}$ & Informing & General public & $\begin{array}{l}\text { Provides the widest possible } \\
\text { audience coverage; } \\
\text { - Makes it possible to } \\
\text { visualize technology. }\end{array}$ & 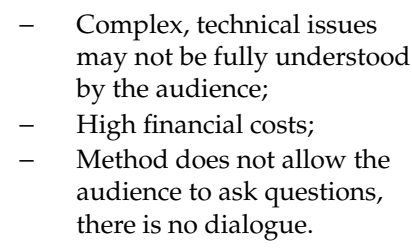 \\
\hline $\begin{array}{l}\text { Websites devoted to carbon capture } \\
\text { and storage technology and specific } \\
\text { CCS projects. }\end{array}$ & Informing/ involvement & $\begin{array}{l}\text { General public with access } \\
\text { to the Internet }\end{array}$ & 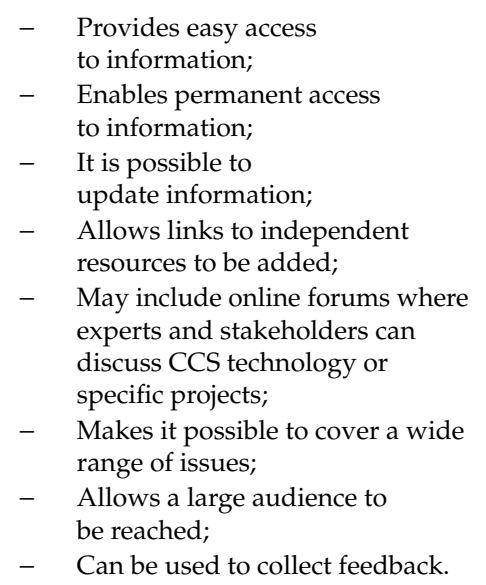 & $\begin{array}{l}\text { - Method does not cover an } \\
\text { audience that does not have } \\
\text { access to a computer and } \\
\text { the Internet. }\end{array}$ \\
\hline
\end{tabular}


Table 1. Cont.

\begin{tabular}{|c|c|c|c|c|}
\hline Method & Objectives of the Method & Target Group & Advantages & Disadvantages \\
\hline $\begin{array}{l}\text { Coverage of environmental issues and } \\
\text { environmental technologies, including } \\
\text { CCS technology, in social networks }\end{array}$ & Informing/ involvement & $\begin{array}{l}\text { General public with access } \\
\text { to the Internet }\end{array}$ & 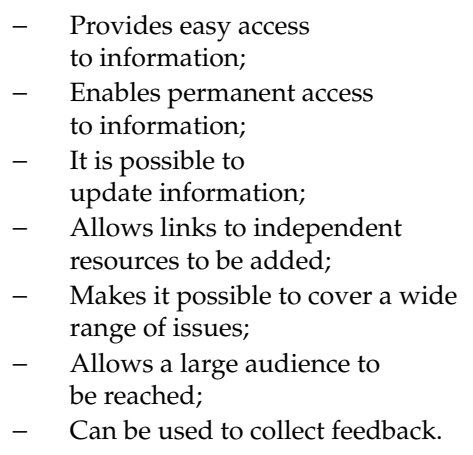 & $\begin{array}{l}\text { Method does not cover an } \\
\text { audience that does not have } \\
\text { access to a computer and } \\
\text { the Internet. }\end{array}$ \\
\hline $\begin{array}{l}\text { Distribution of printed materials (flyers, } \\
\text { brochures, posters, etc.) }\end{array}$ & Informing & General public & $\begin{array}{l}\text { - } \quad \text { Allows a large audience to } \\
\text { be reached; } \\
\text { - } \quad \text { Makes it possible to cover a wide } \\
\text { range of issues; } \\
\text { - } \quad \text { Makes it possible to } \\
\text { visualize technology. }\end{array}$ & $\begin{array}{l}\text { Stakeholders often do not } \\
\text { read printed materials; } \\
\text { - Method does not allow the } \\
\text { audience to ask questions, } \\
\text { there is no dialogue. }\end{array}$ \\
\hline \multicolumn{5}{|l|}{ Event } \\
\hline $\begin{array}{l}\text { Lectures and presentations on } \\
\text { environmental issues and } \\
\text { environmental technologies, including } \\
\text { CCS technology }\end{array}$ & Informing & General public & $\begin{array}{l}\text { Participation of specialists } \\
\text { improves the quality and content } \\
\text { of the information provided; } \\
\text { - Can be used to collect feedback; } \\
\text { - There is a dialogue that } \\
\text { contributes to better } \\
\text { understanding of information; } \\
\text { It is possible to invite media to } \\
\text { cover events. }\end{array}$ & $\begin{array}{ll}\text { - } & \text { A limited audience; } \\
\text { - } & \text { Lectures and presentations are } \\
& \text { limited in time; } \\
\text { - } & \text { Complex, technical issues } \\
\text { may not be fully understood } \\
\text { by the audience. }\end{array}$ \\
\hline
\end{tabular}


Table 1. Cont.

\begin{tabular}{|c|c|c|c|c|}
\hline Method & Objectives of the Method & Target Group & Advantages & Disadvantages \\
\hline Consensus conference & Informing/ involvement & $\begin{array}{l}\text { General public, local } \\
\text { communities }\end{array}$ & $\begin{array}{l}\text { Allows involvement of } \\
\text { stakeholders and identification of } \\
\text { their attitude to CCS technology; } \\
\text { - Participation of specialists } \\
\text { improves the quality and content } \\
\text { of the information provided; } \\
\text { - Can be used to collect feedback; } \\
\text { - There is a dialogue that } \\
\text { contributes to better } \\
\text { understanding of information; } \\
\text { - It is possible to invite media to } \\
\text { cover events. }\end{array}$ & $\begin{array}{l}\text { - The views of participants of } \\
\text { the consensus conference may } \\
\text { not reflect the views of the } \\
\text { general public; } \\
\text { - A limited audience; } \\
\text { - Consensus conferences are } \\
\text { usually limited in time. }\end{array}$ \\
\hline $\begin{array}{l}\text { Exhibitions devoted to environmental } \\
\text { problems and environmental } \\
\text { technologies, including CCS technology }\end{array}$ & Informing & General public & $\begin{array}{l}\text { - Participation of specialists } \\
\text { improves the quality and content } \\
\text { of the information provided; } \\
\text { - There is a dialogue that } \\
\text { contributes to better } \\
\text { understanding of information; } \\
\text { It is possible to invite media to } \\
\text { cover events. }\end{array}$ & $\begin{array}{ll}\text { - } & \text { A limited audience; } \\
\text { - } & \text { Usually limited in time; } \\
\text { - } & \text { Complex, technical issues } \\
\text { may not be fully understood } \\
\text { by the audience. }\end{array}$ \\
\hline Information Centers & Informing/ involvement & Local communities & $\begin{array}{l}\text { Enables permanent access } \\
\text { to information; } \\
\text { - Space can be used for events, } \\
\text { including meetings } \\
\text { with stakeholders; } \\
\text { - Enables stakeholders to receive } \\
\text { comments on the implementation } \\
\text { of CCS technology. }\end{array}$ & $\begin{array}{ll}\text { - } & \text { A limited audience; } \\
\text { - } & \text { High financial costs. }\end{array}$ \\
\hline Stakeholder meetings & Informing/ involvement & $\begin{array}{l}\text { General public, } \\
\text { local communities }\end{array}$ & 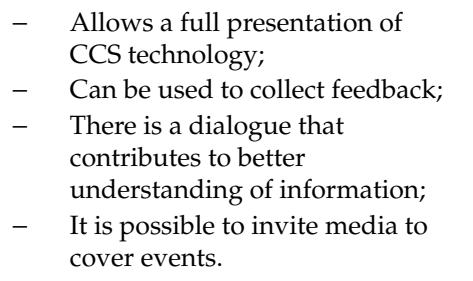 & $\begin{array}{l}\text { - It can be difficult to discuss all } \\
\text { issues that concern } \\
\text { stakeholders who attend } \\
\text { a meeting; } \\
\text { - A limited audience. }\end{array}$ \\
\hline
\end{tabular}


Table 1. Cont.

\begin{tabular}{|c|c|c|c|c|}
\hline Method & Objectives of the Method & Target Group & Advantages & Disadvantages \\
\hline Visit a project site & Informing/ involvement & Local communities & 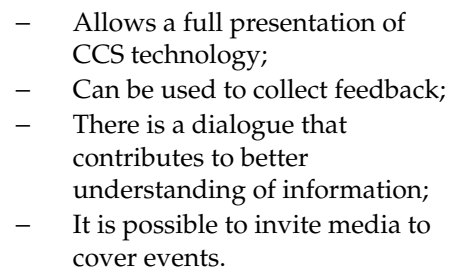 & $\begin{array}{l}\text { - A small number of people can } \\
\text { visit the project site; } \\
\text { - The need to comply with strict } \\
\text { safety rules. }\end{array}$ \\
\hline
\end{tabular}


To increase their effectiveness, measures aimed at CCS technology popularization should be carried out in compliance with the following principles:

1. Timeliness. Engagement with a wide range of stakeholders should begin before the launch of a CCS project. This allows active involvement of interested groups in discussions of significant aspects of the application of carbon dioxide capture and storage technology, in addition to demonstrating that the opinion of civil society has value.

2. Accessibility of information. The global nature of CCS technology implementation determines the need for free access of a wide range of stakeholders to information.

3. Clarity. It is necessary to make information understandable to stakeholders, taking into account the characteristics of the target group.

4. Balance. The implemented methods of carbon dioxide capture and storage technology popularization should disclose both positive and negative aspects of its application.

5. Monitoring and response. Monitoring allows changes in the public perception of CCS technology to be tracked. This also provides information for making a decision about whether any action to adjust the applied popularization strategy is required.

6. Involvement of independent experts. The low level of public trust in business indicates a need to implement state and regional programs to popularize CCS projects with the involvement of independent experts and representatives of academic institutions.

\subsection{Recommendations for the Improvement of Public Databases on the World Practice of Carbon Dioxide} Capture and Storage Technology Implementation

The methods of promoting carbon dioxide capture and storage technology, described above, will help to increase public awareness of all aspects of CCS. However, an important contribution to its widespread acceptance can be made by providing the interested persons with the information on successful global implementation of carbon dioxide capture and storage projects. This will demonstrate the long-term safety and value of the technology.

Despite the relative novelty of CCS technology, according to the National Energy Technology Laboratory's (NETL) Carbon Capture and Storage (CCS) Database [56], carbon dioxide capture and storage technology has been implemented in more than 300 projects in more than 30 countries. Nevertheless, about 25 percent of these projects are frozen, more than 20 percent were canceled as a result of management decisions, and about 10 percent were suspended [33]; 93 projects are in an active stage of implementation, 36 are in development.

Thus, significant experience in the implementation of $\mathrm{CO}_{2}$ capture and storage projects has been accumulated globally. This can be used to demonstrate to a wide range of stakeholders the practical aspects of the application of CCS technology, including the negative and positive consequences of its implementation.

Several public databases contain information on CCS projects (Table 2) 
Table 2. Existing public databases containing information on the global experience of introducing carbon dioxide capture and storage technology.

\begin{tabular}{|c|c|}
\hline Database Name & Information Contained in the Database \\
\hline $\begin{array}{l}\text { The National Energy Technology } \\
\text { Laboratory's (NETL) Carbon Capture } \\
\text { and Storage (CCS) Database }\end{array}$ & $\begin{array}{l}\text { Project name, company, plant name, type of project, project } \\
\text { overall status, plant status, project phase, country location, } \\
\text { state location, specific site location, plant size or capture } \\
\text { amount, combustion/separation, capture technology, amount } \\
\text { of } \mathrm{CO}_{2} \text { captured/stored, project summary, project start date, } \\
\text { project cost, project information webpage. }\end{array}$ \\
\hline $\begin{array}{l}\text { CO2RE (a database of CCS facilities of } \\
\text { the Global CCS Institute) }\end{array}$ & $\begin{array}{l}\text { Project name, country location, type of project, project overall } \\
\text { status, project short description, project start date. } \\
\mathrm{CO}_{2} \text { emissions data, policy, regulatory and storage emissions } \\
\text { data. }\end{array}$ \\
\hline $\begin{array}{l}\text { The CCS project database provided by } \\
\text { the Carbon Capture and Sequestration } \\
\text { Technologies at MIT }\end{array}$ & $\begin{array}{l}\text { Project name, company, location, type of capture technology, } \\
\text { project overall status, project start date, project cost, } \\
\text { economic indicators, project information webpage, project } \\
\text { information and comments, including public attitude. }\end{array}$ \\
\hline
\end{tabular}

Compiled by authors based on [56-58].

The analysis of existing databases on CCS projects allows us to draw the following conclusions:

- The databases are public, thus, information is available to any interested person;

- The databases contain general information about CCS project implementation (place of implementation, name, start date, capital intensity, etc.) and information on technical characteristics (type of project, capacity, etc.);

- The databases do not disclose the consequences of risks confirmed during the projects' implementation, or the impact of these projects on stakeholders;

- Data in the databases are presented in English, which may hinder access to information for non-native English stakeholders;

- The databases contain a list of suspended/closed projects, but the reasons for this are not disclosed.

It should be noted that the CCS project database provided by the Carbon Capture and Sequestration Technologies at MIT [58] contains information on stakeholder perceptions of some projects. However, firstly, this information is random and partial, and secondly, the database was frozen on 30 September 2016.

Thus, we recommend the disclosure of the following significant aspects of the implementation of CCS projects via public databases:

- Information on the reasons for freezing or closing CCS projects;

- Information on the presence/absence of industrial accidents and $\mathrm{CO}_{2}$ leaks that occurred during the implementation of CCS projects;

- Information on negative consequences of industrial accidents and $\mathrm{CO}_{2}$ leaks;

- Description of the mechanisms for monitoring the progress of CCS projects;

- List of organizations and independent observers exercising control over the progress of CCS project implementation;

- Information on social programs implemented during the project and aimed at local communities, infrastructure development, etc.;

- Information on potential CCS projects.

\section{Discussion}

In our opinion, the development of a strategy for carbon dioxide capture and storage technology popularization needs to be carried out taking into account the following provisions: 
1. The public has limited knowledge about CCS technology. This is typical in countries that do not have experience in $\mathrm{CO}_{2}$ capture and storage, or in which similar projects have been implemented in the past or are being implemented at present.

2. Modern society expresses a high level of concern about environmental problems. CCS technology is one solution to these problems. Thus, the popularization of CCS projects can be based on raising public awareness of environmental problems and the perception of $\mathrm{CO}_{2}$ capture and storage technology as the means to solve them.

3. The public shows a high level of concern regarding the safety of CCS technology due to its relative novelty.

4. Carbon dioxide capture and storage projects are local. However, they are characterized by a high degree of risk, and directly or indirectly affect the interests of a wide range of stakeholders [98]. The degree of impact on various stakeholders is different. Thus, the popularization of carbon dioxide capture and storage technology among stakeholders who cannot be characterized as local (from the perspective of the project area) should be based on raising awareness of modern environmental challenges, the content of CCS technology, and the results of implementation of the demonstration projects in different countries.

5. The largest number of risks, including environmental pollution and health damage, is assumed by local stakeholder groups. Thus, the popularization of carbon dioxide capture and storage technology among stakeholders characterized as local (from the perspective of the project area) should be based on raising awareness of environmental challenges, the content of CCS technology, and the results of implementation of the demonstration projects. Furthermore, an effective popularization strategy should additionally include methods of consultation and active involvement of local stakeholders. Government authorities should also be actively involved in the implementation of carbon dioxide capture and storage projects.

In our opinion, the popularization of CCS technology should be based on four analyzed models (the deficit, contextual, lay expertise, and public participation models).

The practical application of the key research results will contribute to the creation of favorable conditions for the global introduction of carbon dioxide capture and storage technology.

At present, there is a significant amount of research devoted to the application of CCS technology in practice $[61,99,100]$ and the importance of interaction with stakeholders $[51,59,60,88]$. Although, as mentioned above, the problems of promoting science and its achievements are being actively considered by researchers, in the scientific literature, the most effective methods for the popularization of carbon capture and storage have not yet been determined, taking into account all its features and risks. In addition, CCS technology has significant potential to solve global environmental problems.

Thus, the authors believe that the key difference between this and previous studies is the developed approach to promoting carbon capture and storage in society on the basis of the global experience of the implementation of CCS projects, and its associated features and risks. The recommended improvement of public databases on the global experience of the implementation of carbon dioxide capture and storage technology will increase the access of a wide range of stakeholders to information. This will allow them to make informed decisions about supporting or opposing individual CCS projects.

The main limitations of the paper are the following:

- Open sources of information were used, so some data on CCS projects may be slightly distorted;

- Although the effectiveness of the application of different methods of popularization of carbon capture and storage technology can vary, it was not evaluated. The authors see this as a direction for further research.

\section{Conclusions}

$\mathrm{CO}_{2}$ capture and storage projects are characterized by a high degree of risk. Furthermore, they directly or indirectly affect the interests of a wide range of stakeholders. Thus, to reduce the social 
risks of technology implementation and increase the efficiency of specific projects, it is necessary to obtain a social license from society.

To develop the most effective strategy for promoting CCS technology, it is necessary to carry out preparatory work aimed at assessing the target audience, and identifying the audience's level of awareness and the reasons for positive or negative attitudes towards technology. The strategy should include a range of measures aimed at raising public awareness of the technology, and its risks and benefits, and actively involving stakeholders in the process of CCS implementation.

The strategy of popularization of carbon dioxide capture and storage technology among stakeholders who cannot be characterized as local should include educational methods and media coverage. The aim should be to raise awareness of modern environmental challenges; the content, risks, and benefits of CCS technology; and the results of implementation of demonstration projects in different countries.

The popularization of carbon dioxide capture and storage technology among local stakeholders, in addition to educational methods and media coverage, should also include methods of consultation and active involvement, such as consensus conferences, stakeholder meetings, visits to a project site, and meetings at information centers.

One of the key components of the popularization of carbon dioxide capture and storage technology is the availability and reliability of related information and the results of the implementation of specific projects for a wide range of stakeholders.

Author Contributions: Conceptualization, A.C., T.C. and S.F.; methodology, T.C. and S.F.; formal analysis, A.C., T.C. and S.F.; investigation, A.C. and T.C.; validation, A.C.; Writing-Original Draft Preparation A.C., T.C. and S.F. All authors have read and agreed to the published version of the manuscript.

Funding: The research was carried out with the financial support of a grant by the Russian Science Foundation (Project No. 18-18-00210, “Development of assessment methodology of public efficiency of projects devoted to carbon dioxide sequestration").

Conflicts of Interest: The authors declare no conflict of interest.

\section{References}

1. Stuart, S. Science, Technology and Global Problems, 1st ed.; Pergamon: London, UK, 1979; 70p.

2. Global Issues Overview. Available online: https://www.un.org/en/sections/issues-depth/global-issuesoverview/ (accessed on 3 July 2020).

3. Global Problems, Global Solutions: Towards Better Global Governance. Available online: https://www.wto. org/english/res_e/booksp_e/public_forum09_e.pdf (accessed on 5 July 2020).

4. Gvishiani, D.M. Trends and Perspectives in Development of Science and Technology and Their Impact on the Solution of Contemporary Global Problems, 1st ed.; Pergamon Press Ltd.: London, UK, 1979; 308p.

5. Ren, F.; Zhai, J. New Developments and Important Issues for Science and Technology Communication and Popularization. In Communication and Popularization of Science and Technology in China; Springer Science and Business Media LLC: Berlin/Heidelberg, Germany, 2014; pp. 321-345.

6. Cooter, R.; Pumfrey, S. Separate Spheres and Public Places: Reflections on the Popularization and Science in Popular Culture. Hist. Sci. 1994, 32, 237-267. [CrossRef]

7. Hanauska, M. Historical aspects of external science communication. In Science Communication; Leßmöllmann, A., Dascal, M., Gloning, T., Eds.; De Gruyter Mouton: Berlin, Germany, 2019; pp. 585-600.

8. Baranov, A.N.; Guseinov, A.A.; Motroshilova, N.V.; Ogurtsov, A.P.; Rubtsov, A.V.; Yudin, B.G. Ideas and Numbers. Grounds and Criteria for Assessing the Effectiveness of Philosophical and Socio-Humanitarian Research, 1st ed.; Progress-Trad.: Moscow, Russia, 2016; 270p.

9. IPCC Special Report <Global Warming of $1.5^{\circ} \mathrm{C}>$. Available online: https://www.ipcc.ch/sr15/ (accessed on 17 June 2020).

10. Transcript of Congressional Testimony of Dr. James Hansen. 1988. Available online: https://www.sealevel. info/1988_Hansen_Senate_Testimony.html (accessed on 7 June 2020). 
11. Moron, V. Greenhouse Gases and Climatic Change. In Global Change, Energy Issues and Regulation Policies; Saulnier, J.B., Varella, M.D., Eds.; Springer Science+Business Media Dordrecht: Berlin/Heidelberg, Germany, 2013; pp. 31-46.

12. Jain, P.C. Greenhouse effect and climate change: Scientific basis and overview. Renew Energy 1993, 3, 403-420. [CrossRef]

13. Climate Change: The IPCC 1990 and 1992 Assessments. Available online: https://www.ipcc.ch/site/assets/ uploads/2018/05/ipcc_90_92_assessments_far_full_report.pdf (accessed on 10 June 2020).

14. Tuckett, R. The role of atmospheric gases in causing climate change and global warming. In Climate Change: Observed Impacts on Planet Earth, 2nd ed.; Letcher, T.M., Ed.; Elsevier: Amsterdam, The Netherlands, 2015; Volume 3, pp. 3-20.

15. Emissions Gap Report 2019 Executive Summary. Available online: https://wedocs.unep.org/bitstream/handle/ 20.500.11822/30798/EGR19ESEN.pdf?sequence=13 (accessed on 16 October 2020).

16. Fossil CO2 and GHG Emissions of All World Countries. Available online: https://ec.europa.eu/jrc/ en/publication/eur-scientific-and-technical-research-reports/fossil-co2-and-ghg-emissions-all-worldcountries-0 (accessed on 23 October 2020).

17. BP Statistical Review of World Energy. 2020. Available online: https://www.bp.com/content/dam/bp/ business-sites/en/global/corporate/pdfs/energy-economics/statistical-review/bp-stats-review-2020-co2emissions.pdf (accessed on 21 October 2020).

18. Statistical Review of World Energy. Available online: https://www.bp.com/en/global/corporate/energyeconomics/statistical-review-of-world-energy.html (accessed on 21 October 2020).

19. Li, M.; Mi, Z.; Coffman, D.M.; Wei, Y.-M. Assessing the policy impacts on non-ferrous metals industry's $\mathrm{CO}_{2}$ reduction: Evidence from China. J. Clean. Prod. 2018, 192, 252-261. [CrossRef]

20. Sun, M.; Wang, Y.; Shi, L.; Klemeš, J.J. Uncovering energy use, carbon emissions and environmental burdens of pulp and paper industry: A systematic review and meta-analysis. Renew Sustain. Energy Rev. 2018, 92, 823-833. [CrossRef]

21. Zeng, S.; Jiang, C.; Ma, C.; Su, B. Investment Efficiency of the New Energy Industry in China. Energy Econ. 2018, 70, 536-544. [CrossRef]

22. Zeng, S.; Nan, X.; Liu, C.; Chen, J. The response of the Beijing carbon emissions allowance price (BJC) to macroeconomic and energy price indices. Energy Policy 2017, 106, 111-121. [CrossRef]

23. Almamoori, A.; Krishnamurthy, A.; Razeai, F.; Rezaei, F. Carbon Capture and Utilization Update. Energy Technol. 2017, 5, 1-17.

24. European Council Meeting (12 December 2019)—Conclusions (EUCO 29/19). Available online: https: //www.consilium.europa.eu/media/41768/12-euco-final-conclusions-en.pdf (accessed on 22 October 2020).

25. Communication from the Commission to the European Parliament, the Council, the European Economic and Social Committee and the Committee of the Regions. Stepping up Europe's 2030 Climate Ambition. Investing in a Climate-Neutral Future for the Benefit of Our People. Available online: https://eur-lex.europa. eu/legal-content/EN/TXT/PDF/?uri=CELEX:52020DC0562\&from=EN (accessed on 22 October 2020).

26. 2030 Climate \& Energy Framework. Available online: https://ec.europa.eu/clima/policies/strategies/2030_en (accessed on 22 October 2020).

27. Ketzer, M.; Iglesias, R.; Einloft, S. Reducing Greenhouse Gas Emissions with CO2 Capture and Geological Storage. In Handbook of Climate Change Mitigation; Chen, W.Y., Seiner, J., Suzuki, T., Lackner, M., Eds.; Springer: New York, NY, USA, 2017; pp. 1405-1440.

28. Romasheva, N.V.; Kruk, M.N.; Cherepovitsyn, A.E. Propagation perspectives of CO2 sequestration in the world. Int. J. Mech. Eng. Technol. 2018, 9, 1877-1885.

29. Hardisty, P.E.; Sivapalan, M.; Brooks, P. The Environmental and Economic Sustainability of Carbon Capture and Storage. Int. J. Environ. Res. Public Health 2011, 8, 1460-1477. [CrossRef]

30. Jiang, K.; Ashworth, P.; Zhang, S.; Liang, X.; Sun, Y.; Angus, D. China's carbon capture, utilization and storage (CCUS) policy: A critical review. Renew Sustain. Energy Rev. 2019, 119, 109601. [CrossRef]

31. Vercelli, S.; Anderlucci, J.; Memoli, R.; Battisti, N.; Mabon, L.; Lombardi, S. Informing People about CCS: A Review of Social Research Studies. Energy Procedia 2013, 37, 7464-7473. [CrossRef]

32. A Brief History of CCS and Current Status. Available online: https://ieaghg.org/docs/General_Docs/ Publications/Information_Sheets_for_CCS_2.pdf (accessed on 13 June 2020). 
33. Romasheva, N.; Ilinova, A. CCS Projects: How Regulatory Framework Influences Their Deployment. Resources 2019, 8, 181. [CrossRef]

34. Manning, D.A.C.; Renforth, P. Passive sequestration of atmospheric CO2 through coupled plant-mineral reactions in urban soils. Environ. Sci. Technol. 2013, 47, 135-141. [CrossRef] [PubMed]

35. Jorat, M.E.; Goddard, M.A.; Manning, P.; Lau, H.K.; Ngeow, S.; Sohi, S.P.; Manning, D.A.C. Passive CO2 removal in urban soils: Evidence from brownfield sites. Sci. Total Environ. 2020, 703, 135573. [CrossRef] [PubMed]

36. Washbourne, C.L.; Lopez-Capel, E.; Renforth, P.; Ascough, P.L.; Manning, D.A.C. Rapid removal of atmospheric CO2 by urban soils. Environ. Sci. Technol. 2015, 49, 5434-5440. [CrossRef] [PubMed]

37. Jo, H.K.; McPherson, G.E. Carbon storage and flux in urban residential greenspace. J. Environ. Manag. 1995, 45, 109-133. [CrossRef]

38. Xi, F.; Davis, S.J.; Ciais, P.; Crawford-Brown, D.; Guan, D.; Pade, C.; Shi, T.; Syddall, M.; Lv, J.; Ji, L.; et al. Substantial global carbon uptake by cement carbonation. Nat. Geosci. 2016, 9, 880-883. [CrossRef]

39. Minx, J.; Lamb, W.; Callaghan, M.; Fuss, S.; Hilaire, J.; Creutzig, F.; Amann, T.; Beringer, T.; de Oliveira Garcia, W.; Hartmann, J.; et al. Negative emissions: Part 1-Research landscape and synthesis. Environ. Res. Lett. 2018, 13, 063001. [CrossRef]

40. Cox, E.; Spence, E.; Pidgeon, N. Public perceptions of carbon dioxide removal in the United States and the United Kingdom. Nat. Clim. Chang. 2020, 10, 1-6. [CrossRef]

41. Arning, K.; Offermann-van, J.; Linzenich, A.; Kaetelhoen, A.; Sternberg, A.; Bardow, A.; Ziefle, M. Same or different? Insights on public perception and acceptance of carbon capture and storage or utilization in Germany. Energy Policy 2019, 125, 235-249. [CrossRef]

42. CCU and CCS-Building Blocks for Climate Protection in Industry (Acatech Position Paper), Munich. 2019. Available online: https://www.acatech.de/wp-content/uploads/2018/09/acatech_POSITION_CCU_CCS_engl_ Web.pdf (accessed on 24 October 2020).

43. Fogarty, J.; McCally, M. Health and safety risks of carbon capture and storage. JAMA 2010, 303, 67-68. [CrossRef] [PubMed]

44. Regulation of Carbon Capture and Storage. Available online: https://irgc.org/wp-content/uploads/2018/09/ Policy_Brief_CCS3.pdf (accessed on 22 June 2020).

45. Terwel, B.W.; Dancker, D.L.D. Initial public reactions to carbon capture and storage (CCS): Differentiating general and local views. Clim. Policy 2012, 12, 288-300. [CrossRef]

46. Chrysostomidis, I.; Perumalpillai, S.; Bohm, M.; Crombie, M.; Beynon, E.; Lee, A. CO2 Capture Project's CCS Stakeholder Issues Review and Analysis. Energy Procedia 2013, 37, 7832-7839. [CrossRef]

47. Bradbury, J.A. Public understanding of and engagement with CCS. In The Social Dynamics of Carbon Capture and Storage: Understanding CCS Representations, Governance and Innovation, 1st ed.; Markusson, N., Shackley, S., Evar, B., Eds.; Routledge: London, UK, 2012; pp. 172-188.

48. Boomsma, C.; Mors, E.T.; Jack, C.; Broecks, K.; Buzoianu, C.; Cismaru, D.M.; Peuchen, R.; Piek, P.; Schumann, D.; Shackley, S.; et al. Community compensation in the context of Carbon Capture and Storage: Current debates and practices. Int. J. Greenh. Gas Control 2020, 101, 103128. [CrossRef]

49. Mors, E.T.; Terwel, B.W.; Daamen, D.D.L. The potential of host community compensation in facility siting. Int. J. Greenh. Gas Control 2012, 11, 130-138. [CrossRef]

50. Duetschke, E. What drives local public acceptance-Comparing two cases from Germany. Energy Procedia 2011, 4, 6234-6240. [CrossRef]

51. Lockwood, T. Public Outreach Approaches for Carbon Capture and Storage Projects; IEA Clean Coal Centre: London, UK, 2017.

52. Brunsting, S.; de Best-Waldhober, M.; Terwel, B.W. ‘I Reject your Reality and Substitute my Own!' Why More Knowledge about CO2 Storage Hardly Improves Public Attitudes. Energy Procedia 2013, 37, 7419-7427. [CrossRef]

53. Report of the Royal Society <The Public Understanding of Science>. Available online: https://royalsociety. org/-/media/Royal_Society_Content/policy/publications/1985/10700.pdf (accessed on 1 June 2020).

54. House of Lords. Science and Technology_Third Report. Available online: https://publications.parliament. uk/pa/ld199900/ldselect/ldsctech/38/3801.htm (accessed on 1 June 2020). 
55. Science and the Public: Mapping Science Communication Activities. Available online: https://assets.publishing.service.gov.uk/government/uploads/system/uploads/attachment_data/file/ 260650/science-and-public-mapping-science-communication-activities.pdf (accessed on 5 June 2020).

56. The National Energy Technology Laboratory's (NETL) Carbon Capture and Storage (CCS) Database. Available online: https://www.netl.doe.gov/coal/carbon-storage/worldwide-ccs-database (accessed on 27 June 2020).

57. Global CCS Database. Available online: https://www.globalccsinstitute.com/resources/co2re/ (accessed on 25 June 2020).

58. Carbon Capture and Sequestration Project Database. Available online: https://sequestration.mit.edu/tools/ projects/ (accessed on 29 June 2020).

59. Communications for Carbon Capture and Storage: Identifying the Benefits, Managing Risk and Maintaining the Trust of Stakeholders. Available online: https://www.globalccsinstitute.com/archive/hub/publications/ 92266/communications-carbon-capture-storage.pdf (accessed on 16 June 2020).

60. Ashworth, P. Lessons from Project Level Community Engagement. Ash Research. 2010. Available online: https://www.globalccsinstitute.com/archive/hub/publications/198173/lessons-project-levelcommunity-engagement.pdf (accessed on 12 June 2020).

61. IPCC Special Report on Carbon Dioxide Capture and Storage. Available online: https://www.ipcc.ch/report/ srccs/ (accessed on 20 June 2020).

62. Sharp, J. Carbon Capture and Storage: The Views of the Canadian Public. Available online: https: //www.pembina.org/reports/ccs-discuss-public-views.pdf (accessed on 6 June 2020).

63. Bauer, M.; Allum, N.; Miller, S. What Can We Learn from 25 Years of PUS Survey Research? Liberating and Expanding the Agenda. Public Underst. Sci. 2007, 16, 79-95. [CrossRef]

64. Short, D. The public understanding of science: 30 years of the Bodmer report. Sch. Sci. Rev. 2013, 95, 39-44.

65. Bauer, M.W. The evolution of public understanding of science-Discourse and comparative evidence. Sci. Technol. Soc. 2009, 14, 221-240. [CrossRef]

66. Evans, G.; Durant, J. The relationship between knowledge and attitudes in the public understanding of science in Britain. Public Underst. Sci. 1995, 4, 57-74. [CrossRef]

67. Einsiedel, E. Mental maps of science: Knowledge and attitudes among canadian adults. Int. J. Public. Opin. R. 1994, 6, 35-44. [CrossRef]

68. Holden, C. From PUS to PEST. Science 2002, 298, 49.

69. Schäfer, M. From Public Understanding to Public Engagement an Empirical Assessment of Changes in Science Coverage. Sci. Commun. 2009, 30, 475-505. [CrossRef]

70. Lewenstein, B.V. Models of Public Communication of Science and Technology. Available online: https://ecommons.cornell.edu/bitstream/handle/1813/58743/Lewenstein.2003.Models_of_communication. CC\%20version\%20for\%20Cornell\%20eCommons.pdf?sequence=3\&isAllowed=y (accessed on 13 June 2020).

71. House of Commons. Science and Technology Committee. Science Communication and Engagement. Available online: https://publications.parliament.uk/pa/cm201617/cmselect/cmsctech/162/162.pdf (accessed on 3 June 2020).

72. Demuijnck, G.; Fasterling, B. The Social License to Operate. J. Bus. Ethics 2016, 136, 675-685. [CrossRef]

73. Litvinenko, V.S.; Tsvetkov, P.S.; Molodtsov, K.V. The social and market mechanism of sustainable development of public companies in the mineral resource sector. Eurasian Min. 2020, 1, 36-41. [CrossRef]

74. Jonek-Kowalska, I.; Ponomarenko, T.V.; Marinina, O.A. Problems of interaction with stakeholders during implementation of long-term mining projects. J. Mini. Inst. 2018, 232, 428-437.

75. Social Licence to Operate Paper. Available online: https://www.sbc.org.nz/_data/assets/pdf_file/0005/99437/ Social-Licence-to-Operate-Paper.pdf (accessed on 22 October 2020).

76. Prno, J.; Slocombe, D. Exploring the origins of 'social license to operate' in the mining sector: Perspectives from governance and sustainability theories. Resour. Policy 2012, 37, 346-357. [CrossRef]

77. Thomson, I.; Boutilier, R. Social License to Operate. In SME Mining Engineering Handbook, 3rd ed.; Darling, P., Ed.; SME: Littleton, CO, USA, 2011; pp. 1779-1796.

78. National Academies of Sciences, Engineering, and Medicine. Communicating Science Effectively: A Research Agenda. Available online: https://sciencedev.net/Docs/222222222222.pdf (accessed on 9 June 2020).

79. Budinis, S.; Krevor, S.; Dowell, N.; Brandon, N.; Hawkes, A. An assessment of CCS costs, barriers and potential. Energy Strategy Rev. 2018, 22, 61-81. [CrossRef] 
80. Viebahn, P.; Chappin, E. Scrutinising the Gap between the Expected and Actual Deployment of Carbon Capture and Storage-A Bibliometric Analysis. Energies 2018, 11, 2319. [CrossRef]

81. Fischedick, M.; Pietzner, K.; Supersberger, N.; Esken, A.; Kuckshinrichs, W.; Zapp, P.; Linßen, J.; Schumann, D.; Radgen, P.; Cremer, C.; et al. Stakeholder acceptance of carbon capture and storage in Germany. Energy Procedia 2009, 1, 4783-4787. [CrossRef]

82. de Best-Waldhober, M.; Daamen, D.; Faaij, A.P.C. Informed and uninformed public opinions on CO2 capture and storage technologies in the Netherlands. Int. J. Greenh. Gas Control 2009, 3, 322-332. [CrossRef]

83. Miller, E.; Summerville, J.; Buys, L.; Bell, L. Initial public perceptions of carbon geosequestration: Implications for engagement and environmental risk communication strategies. Int. J. Global Environ. Issues 2008, 8 , 147-164. [CrossRef]

84. Fedoseev, S.; Cvetkov, P. Key factors of public perception of carbon dioxide capture and storage projects. J. Mini. Inst. 2019, 237, 361-368. [CrossRef]

85. Carley, S.R.; Krause, R.M.; Warren, D.C.; Rupp, J.A.; Graham, J.D. Early Public Impressions of Terrestrial Carbon Capture and Storage in a Coal-Intensive State. Environ. Sci. Technol. 2012, 46, 7086-7093. [CrossRef]

86. Leiss, W.; Larkin, P. Risk communication and public engagement in CCS projects: The foundations of public acceptability. Int. J. Risk Assess Manag. 2019, 22, 384-403. [CrossRef]

87. Guidelines for Community Engagement in Carbon Dioxide Capture, Transport, and Storage Projects. World Resources Institute. 2010. Available online: http://pdf.wri.org/ccs_and_community_engagement.pdf (accessed on 14 June 2020).

88. Hund, G.; Greenberg, S.E. Dual-track CCS stakeholder engagement: Lessons learned from FutureGen in Illinois. Energy Procedia 2011, 4, 6218-6225. [CrossRef]

89. Brunsting, S.; Best-Waldhober, M.; Feenstra, C.F.J.; Mikunda, T. Stakeholder participation practices and onshore CCS: Lessons from the Dutch CCS Case Barendrecht. Energy Procedia 2011, 4, 6376-6383. [CrossRef]

90. Hammond, J.; Shackley, S. Towards a Public Communication and Engagement Strategy for Carbon Dioxide Capture and Storage Projects in Scotland. Working Paper SCCS 2010-08. 2010. Available online: https://pdfs.semanticscholar.org/0abf/809880760fbe2e80b2c59439005db5a89e49.pdf?_ga=2. 157552314.1249037730.1596989467-1321645145.1596989467 (accessed on 4 June 2020).

91. Vasilev, Y.N.; Tsvetkova, A.Y. International review of public perception of ccs technologies. Int. Multidiscip. Sci. GeoConf. SGEM 2019, 19, 415-422.

92. Ashworth, P.; Pisarski, A.; Thambimuthu, K. Public acceptance of carbon dioxide capture and storage in a proposed demonstration area. PI Mech. Eng. A J. Pow 2008, 223, 299-304. [CrossRef]

93. de Best-Waldhober, M.; Daamen, D.; Ramirez, A.R.; Faaij, A.; Hendriks, C.; de Visser, E. Informed public opinion in the Netherlands: Evaluation of $\mathrm{CO}_{2}$ capture and storage technologies in comparison with other CO2 mitigation options. Int. J. Greenh. Gas Control 2012, 10, 169-180. [CrossRef]

94. Itaoka, K.; Dowd, A.; Saito, A.; Paukovic, M.; de Best-Waldhober, M.; Ashworth, P. Relating Individual Perceptions of Carbon Dioxide to Perceptions of CCS: An International Comparative Study. Energy Procedia 2013, 37, 7436-7443. [CrossRef]

95. Simis, M.J.; Madden, H.; Cacciatore, M.A.; Yeo, S.K. The lure of rationality: Why does the deficit model persist in science communication? Public Underst. Sci. 2016, 25, 400-414. [CrossRef]

96. Economic and Social Research Council. Reconsidering Public Attitudes and Public Acceptance of Renewable Energy Technologies: A Critical Review. Available online: http://geography.exeter.ac.uk/beyond_nimbyism/ deliverables/bn_wp1_4.pdf (accessed on 19 June 2020).

97. Understanding Public Responses to Low Carbon Technologies. Available online: https://www.europarl. europa.eu/RegData/etudes/IDAN/2019/624292/EPRS_IDA(2019)624292_EN.pdf (accessed on 15 June 2020).

98. Cherepovitsyn, A.E.; Ilinova, A.A.; Evseeva, O.O. Stakeholders management of carbon sequestration project in the state-Business-Society system. J. Mini. Inst. 2019, 240, 731-742. [CrossRef] 
99. Anderson, S.; Newell, R. Prospects for Carbon Capture and Storage Technologies; Resources for the Future. 2003. Available online: http://www.rff.org/files/sharepoint/WorkImages/Download/RFF-DP-02-68.pdf (accessed on 23 June 2020).

100. Leung, D.Y.C.; Caramanna, G.; Maroto-Valer, M.M. An overview of current status of carbon dioxide capture and storage technologies. Renew Sustain. Energy Rev. 2014, 39, 426-443. [CrossRef]

Publisher's Note: MDPI stays neutral with regard to jurisdictional claims in published maps and institutional affiliations.

(C) 2020 by the authors. Licensee MDPI, Basel, Switzerland. This article is an open access article distributed under the terms and conditions of the Creative Commons Attribution (CC BY) license (http://creativecommons.org/licenses/by/4.0/). 